\title{
Cysteine-Rich Hydrophobic Domain 2 Protein
}

National Cancer Institute

\section{Source}

National Cancer Institute. Cysteine-Rich Hydrophobic Domain 2 Protein. NCI Thesaurus.

Code C97408.

Cysteine-rich hydrophobic domain 2 protein (165 aa, $19 \mathrm{kDa}$ ) is encoded by the human CHIC2 gene. This protein may play a role in cytoplasmic vesicle transport. 